\title{
Geographic Distribution and Evaluation of Saccharomyces cerevisiae Strains Isolated from Vineyards in the Warmer, Inland Regions of the Western Cape in South Africa
}

\author{
W. Khan', O.P.H. Augustyn ${ }^{1}$, T.J. van der Westhuizen ${ }^{2}$, M.G. Lambrechts ${ }^{3}$ and I.S. Pretorius ${ }^{3}$
}

1) ARC-Fruit, Vine and Wine Research Institute, Nietvoorbij Centre for Vine and Wine, Private Bag X5026, 7599 Stellenbosch, South Africa

2) Anchor Yeast, P.O. Box 14, 7475 Eppindust (Cape Town), South Africa

3) Institute for Wine Biotechnology, Department of Viticulture and Oenology, University of Stellenbosch, Private Bag X1, 7602 Matieland (Stellenbosch), South Africa

Submitted for publication: September 1999

Accepted for publication: February 2000

Key words: Wine yeasts, yeast biodiversity, yeast ecology, biogeography, indigenous yeast flora

\begin{abstract}
The aim of this study was to examine the geographic distribution of Saccharomyces cerevisiae strains indigenous to 19 sites in the warmer, inland regions of the Western Cape in South Africa. These strains were compared to those isolated previously from the cooler, coastal regions of the same province by subjecting both sets of organisms to the same characterisation procedures. Thirty isolates per sampling site were isolated and the $S$. cerevisiae strains subjected to the following characterisation procedures; karyotyping using pulse field gel electrophoresis (CHEF), randomly amplified polymorphic DNA, the polymerase chain reaction technique (RAPD-PCR), Sugar fermentation ability, flocculation ability, stress resistance/response and extracellular enzyme activity. When considering biodiversity per sampling site, CHEF karyotypes indicated the recovery of $30 \mathrm{~S}$. cerevisiae strains. This number was reduced to 21 when comparing banding patterns over sites. Addition of RAPD-PCR data expanded the number of unique strains to 29. Subsequent consideration of sugar fermentation data indicated that one of the strians with exactly equivalent CHEF and RAPD-PCR patterns was in fact galactose positive while the other was galactose negative. These data clearly indicate that characterisation of yeast strains by application of a single technique is not a sound practice. None of the $S$. cerevisiae strains isolated in this study occurred in the coastal regions. In addition, each site sampled in this study had its own unique collection of wine yeast strains and no strain common to all sites in the study region was found. Survival mechanisms of $S$. cerevisiae are obscure. Although we found that many of the isolated strains could grow invasively/form pseudohyphae and that these abilities could therefore contribute to the organism's overwintering ability, other mechanisms must also be involved.
\end{abstract}

Traditionally all wine was made from grape must by simply allowing the yeasts, associated with grape berries, to spontaneously ferment the sugars to ethanol, carbon dioxide and other minor, but important, metabolites. It is an accepted fact that strains of the species Saccharomyces cerevisiae, known as the 'wine yeast', are especially well adapted to this process and play the major role in fermenting grape must to wine (Rankine, 1968; Martini \& Vaughan-Martini, 1990; de Barros Lopes, Soden \& Godden, 1998). However, the first phases of spontaneous alcoholic fermentation are usually carried out by a series of non-Saccharomyces species, which contribute to wine aroma (Bisson \& Kunkee, 1991). In the following stages, a succession of different $S$. cerevisiae strains are established which, in turn, provide a large number of volatile compounds (Peynaud \& Domerq, 1959; Bisson \& Kunkee, 1991).

Research carried out on the effect of fermentative metabolism of yeast on wine aroma has confirmed that strains of $S$. cerevisiae contribute quite significantly to the character, quality and aroma of wine (Houtman \& Du Plessis, 1986). It is, however, well- known that strains of $S$. cerevisiae are not abundant amongst the natural microflora of grapes (Peynaud \& Domerq, 1959; Van Zyl \& Du Plessis, 1961; Martini, Ciani \& Scorzetti, 1996). Some authors have argued that the wine yeasts naturally present on grapes are not sufficient to conduct an effective conversion of grape must to wine, and that $S$. cerevisiae strains resident on various surfaces in established wineries play an important role in this regard (Peynaud \& Domerq, 1959; Van Zyl \& Du Plessis, 1961; Rosini, 1984; Martini et al., 1996). In contrast, other research indicates the opposite, i.e. that the vineyard is the primary source of wine yeasts (Török et al., 1996). Furthermore, a series of parameters contributing to the genetic diversity of S. cerevisiae yeast strains in vineyards have been identified (Haba, Mullet \& Berna, 1997). These factors include amongst others: the age of the vineyard; grape variety; viticultural and oenological practices; climatic conditions and geographic location of the vineyard (Martini, Frederichi \& Rosini, 1980; Rosini, Federici \& Martini, 1982; Fleet, Lafon-Lafourcade \& Ribéreau-Gayon, 1984; Parrish \& Corrol, 1985). 
Spontaneous fermentation generally takes longer than most winemakers care to admit and the outcome is not always what was anticipated (Fugelsang, 1996). It is for this reason that Müller-Thurgau introduced for the first time in 1890 the concept of inoculating grape must with pure yeast cultures, thereby establishing numerical dominancy of an actively growing $S$. cerevisiae strain with respect to indigenous yeast strains (Pretorius \& Van der Westhuizen, 1991; Pretorius, 2000). With the emergence of large-scale wine production where rapid, reliable fermentations are essential for consistent wine flavour and predictable quality, the first commercial active dry wine yeast was released in 1965 in California (Fugelsang, 1996). Today, however, the winemaking community is still widely divided with regard to the philosophy and practice of seeding grape must with pure yeast starter cultures. There are those who use solely the native microbial flora originating from the grape and winery environment. Others prefer to begin with native yeasts and later inoculate $S$. cerevisiae starters, while another group use $S$. cerevisiae starters but at lower than recommended inoculum levels (Fugelsang, 1996). Notwithstanding the fact that the cast of characters, and the individual and collective contribution of the native yeast strains to wine varies according to their quantitative and qualitative distribution, it is estimated that approximately $80 \%$ of the world's wines are still produced using any one of these variations of spontaneous fermentation (Heard, 1999).

Stylistic distinction is, apparently, the primary driving force that tempts winemakers of especially the 'old world' and 'boutique' wineries, who are more dependent on vintage variability, to accept the risks involved in unpredictable native yeast fermentations (Fugelsang, 1996; Pretorius, Van der Westhuizen \& Augustyn, 1999). It is believed that, sensorially, native yeast strains introduce a wider variety of flavour- and odour-active characters, resulting in wines that are often described as having 'a more complex, fuller, rounder palate structure' (Fugelsang, 1996). This is most probably because of the presence of low, but detectable, concentrations of reducing sugar as well as higher concentrations of glycerol and other polyols, esters and aldehydes (Fugelsang, 1996; Heard, 1999). Furthermore, the contributions to wine character by native yeast fermentation are not restricted to flavour and bouquet, because the extended lag phase before the onset of vigorous fermentation could also have an important effect (Fugelsang, 1996). In this regard, reaction of oxygen with anthocyanins and other phenols, in the absence of ethanol, was shown to enhance colour stability in red wines as well as accelerating phenol polymerisation (Zoecklein et al., 1995). These findings support observations that wines made in different areas from the same grape variety, with apparently similar fruit composition and processing, often taste noticeably different.

It may be that variations in the microflora naturally present in the different areas contribute to the flavour differences between the wines. It is therefore not surprising that there has been renewed interest among many winemakers in utilising indigenous yeast strains to improve the sensory quality of their wines. In fact, Heard (1999) speculates that the future in winemaking will include mixed culture yeast starters tailored to reflect the characteristics of a given region. As a consequence, yeast biodiversity, biogeography and ecology once again became a focal point of wine microbiology in almost every wine-producing country. South Africa did not lag behind and launched an extensive, long-term biogeographical survey coupled to strain selection and strain development programmes aimed at providing suitable yeasts for use under local winemaking conditions (Pretorius et al., 1999).

Morphological and physiological characteristics, which differ in the various yeasts, are often used as criteria in these biogeographical and breeding studies (Barnett, Payne \& Yarrow, 1983; Kurtzman \& Fell, 1998). For example, the proteincontaining toxin secreted by zymocidal yeasts is able to kill sensitive yeast and can be counted among the defining biochemical characteristics of certain yeasts (Bussey et al., 1982). Other physiological and biochemical characteristics which may be used to characterise yeasts include, amongst others, fermentation of sugars, flocculation ability, stress resistance and extracellular enzyme activity. Furthermore, contemporary yeast classification has been dominated by molecular taxonomy. Related yeasts generally share a higher amount of their genome sequence, implying that methods that measure DNA similarity are useful in defining species. More importantly, molecular comparisons allow for the discernment of yeasts at the strain level which is not always possible when using classic tests (Naumov et al., 1992; Cardinali \& Martini, 1994). Molecular biological techniques, such as the amplification of polymorphic DNA fragments by the polymerase chain reaction (PCR) technique and the separation of chromosomes (varying in length) by pulse field gel electrophoresis (chromosome length polymorphisms, CLPs), are among the classification techniques currently being carried out in an effort to positively identify different $S$. cerevisiae strains on the basis of their genetic sequence (Van der Westhuizen \& Pretorius, 1992; Naumov, Naumova \& Gaillardin, 1993; Vaughan-Martini, Martini \& Cardinali, 1993; De Barros Lopes et al., 1996; Van der Westhuizen et al., 1999; Van der Westhuizen, Augustyn \& Pretorius, 2000a; Van der Westhuizen et al., 2000b).

Biogeographical surveys and studies on genetic diversity of S. cerevisiae strains have emphasised the dynamic nature of yeast populations investigations (Benda, 1964; Frezier \& Dubourdieu, 1992; Vézinhet et al., 1992; Schütz \& Gafner, 1994; Versavaud et al., 1995; Cavalieri et al., 1998; Van der Westhuizen et al., 1999, 2000a). Schütz \& Gafner (1994) indicated that yeast populations should be considered vineyard (terroir) and vintage dependent. While some evidence coupling one or two strains of $S$. cerevisiae to a specific area has been presented (Vézinhet et al., 1992; Versavaud et al., 1995), generally data seem to indicate little correlation between geographic location and genetic affinity (Versavaud et al., 1995; Van der Westhuizen et al., 1999, 2000a). On the other hand, a high level of biodiversity has been indicated in yeast populations within defined areas. This biodiversity represents a valuable resource from which new yeasts can be developed (Cavalieri et al., 1998).

The mechanism enabling yeasts, which are present on grapes and vines during the growth season, to survive winter is unknown (Martini et al., 1996). Filamentous growth in $S$. cerevisiae in response to stress conditions (e.g. nitrogen starvation) was first reported by Gimeno et al. (1992). Later work indicated that the ability of certain strains of $S$. cerevisiae to form pseudohyphae and grow invasively on solid media was somehow co-regulated 
with the production of certain extracellular enzymes (e.g. glucoamylases) and cell aggregation (e.g. flocculation) (Lambrechts et al., 1996; Carstens, Lambrechts \& Pretorius, 1998). It therefore seems likely that yeast cells could form filaments in response to several kinds of stimuli. The ability to form filaments and concomitant attachment to solid substrates could conceivably be one of the survival mechanisms of wine yeasts.

The goal of this study, as part of the long-term biogeographical and strain development programme described by Pretorius et al. (1999), was to examine $S$. cerevisiae biodiversity in the warmer, inland wine-growing regions of the Western Cape in South Africa. Results were then compared to those generated by Van der Westhuizen et al. $(2000 \mathrm{a}, \mathrm{b})$. who examined the wine yeasts present on grapes in the cooler, coastal regions of the same province. In addition, the ability of wine-associated strains of $S$. cerevisiae to form pseudohypahae was examined. The presence or absence of this ability could not only possibly shed light on the organism's overwintering ability, but could also be used as a parameter by which to characterise yeast strains.

\section{MATERIALS AND METHODS}

Areas sampled: Grapes were harvested during the 1997 season at 19 different sites. Areas sampled included: Villiersdorp, Robertson (two sites), Nuy, Du Toits Kloof, Bonnievale, Ashton, Montagu (two sites), Rawsonville, Riebeek-Kasteel (two sites), Porterville (two sites), Wolseley, Malmesbury (two sites), Slanghoek and Tulbagh. The classification of the climate in these areas according to the Le Roux (1974) system [based on the Amerine \& Winkler (1944) system] of degree days over the harvest season (September-March in the Western Cape) is presented in Table 1.

Isolation of yeast strains: The technique described by Van der Westhuizen et al. (2000a) was used. Approximately $1 \mathrm{~kg}$ of grapes was sampled at each site. $S$. cerevisiae was specifically selected for by examining whether these isolates were able to utilise galactose as sole carbon source and unable to utilise lysine as sole nitrogen source. Methylene blue agar plates, buffered at $\mathrm{pH} 4.5$, were used to detect zones of growth inhibition cause by the $\mathrm{K}_{2}$ killer toxin secreted by killer yeasts (Van der Westhuizen et al., 2000a). Unique $S$. cerevisiae strains were stored as glycerol stocks [800:1 YPD medium (1\% yeast extract, $2 \%$ peptone, $2 \%$ glucose) and 800: $180 \%$ glycerol] in a $-85^{\circ} \mathrm{C}$ Ultralow Freezer (Nuaire Equipment), for further use.

Comparison of yeast isolated in inland and coastal regions: $S$. cerevisiae strains isolated in this study were compared to the 51 yeasts isolated from the cooler, coastal regions by Van der Westhuizen et al. (2000a) during the 1995 season. These strains were also compared (CHEF DNA profiles only) to all the other strains of S. cerevisiae isolated (Van der Westhuizen et al., 2000a, b) in 1996, 1997 and 1998 (data not shown).

Separation of intact chromosomal DNA by pulse field gel electrophoresis: The technique described by Van der Westhuizen et al. (2000a) was used. Chromosomal DNA samples were prepared according to the embedded-agarose procedure of Carle \& Olsen (1985). Electrophoretic karyotypes were determined for the 30 yeast isolates per sample. A standard reference strain (VIN 13) was used on each CHEF gel. The banding pattern of each

\section{TABLE 1}

Classification of warmer, inland areas and cooler, coastal areas (Van der Westhuizen et al., 2000a) according to the Le Roux (1974) system of degree days over the harvest season (September-March in the Western Cape).

\begin{tabular}{|l|c|}
\hline \multicolumn{1}{|c|}{ Areas } & $\begin{array}{c}\text { Le Roux } \\
\text { system of } \\
\text { classification }\end{array}$ \\
\hline Warmer, inland areas & \\
\hline Ashton & IV \\
Bonnievale & IV \\
Du Toits Kloof & IV \\
Malmesbury - Site 1 & III \\
Malmesbury - Site 2 & IV \\
Montagu (Both Sites) & IV \\
Nuy & IV \\
Porterville (Both Sites) & V \\
Rawsonville & IV \\
Riebeek-Kasteel (Both Sites) & IV \\
Robertson (Both Sites) & IV \\
Slanghoek & IV \\
Tulbagh & IV \\
Villiersdorp & III \\
Wolseley & IV \\
\hline Cooler, coastal areas & \\
\hline Constantia & II \\
Hermanus & III \\
Stellenbosch & III \\
Somerset West & III \\
\hline
\end{tabular}

yeast isolate was digitised and compared to all the other patterns, as well as all other $S$. cerevisiae strains previously analysed at our institute, using a customised computer programme. Computer and visual data were used as primary criteria when comparing strains. Final results were confirmed by running additional gels.

Randomly amplified polymorphic DNA (RAPD-PCR) analysis: The technique described by Van der Westhuizen et al. (2000b) was used. Yeast cells were cultured and the DNA isolation was performed using the method as described by Van der Westhuizen \& Pretorius (1992). Decamer oligonucleotides of random sequence were purchased from Operon Technologies (Alameda, CA). Five primers (OPC-02, OPC-07, OPC-08, OPC09 and $\mathrm{OPC}-13$ ) from the Operon Kit $\mathrm{C}$ were used to determine their differentiating ability. PCR products were separated using $\mathrm{CHEF}$ electrophoresis. Gels were run for $5.5 \mathrm{~h}$ at a constant voltage of $200 \mathrm{~V}$. The pulse duration was $1 \mathrm{~s}$ with no ramp. Gels were stained with ethidium bromide $(10 \mathrm{mg} / \mathrm{mL})$, viewed on a transilluminator and photographed.

Fermentation ability: The fermentation ability of the yeast strains was determined as described in Kreger-van Rij (1984). A 
$6 \%$ solution of each of the following carbon sources was prepared: glucose, galactose, maltose and sucrose. In addition, a $12 \%$ solution of raffinose was also prepared. All these sugar solutions were sterilised by means of sterile filtration. Two millilitres of each respective sugar solution was added to $4 \mathrm{~mL}$ of a sterile basal medium ( $0.3 \mathrm{~g}$ yeast extract, $0.5 \mathrm{~g}$ peptone) in test-tubes containing Durham tubes. A milky suspension of yeast cells was prepared with $1 \mathrm{~mL}$ of sterile distilled water and $0.1 \mathrm{~mL}$ of this suspension was used to inoculate the $6 \mathrm{~mL}$ solution of sugar plus basal medium. This application was performed in duplicate for all yeast strains. the test-tubes were incubated at $30^{\circ} \mathrm{C}$ for 3 days, after which the production of gas in the Durham tubes was recorded.

Flocculation assay: Flocculation ability was examined by growing cultures in YPD medium, YPGE medium $[1 \%$ yeast extract, $2 \%$ peptone, $3 \mathrm{~mL} / 100 \mathrm{~mL}$ glycerol and (after autoclaving at $121^{\circ} \mathrm{C}$ for $\left.15 \mathrm{~min}\right) 2 \mathrm{~mL} / 100 \mathrm{~mL}$ ethanol] and $\mathrm{YDC}$ flocculation medium ( $8 \%$ glucose and $0.5 \%$ yeast extract) containing either $0 \%$ or $1 \% \mathrm{CaCl}_{2}$ (Carstens et al., 1998). All procedures were done in duplicate. These cultures were incubated at $30^{\circ} \mathrm{C}$ for 3 days with EDTA $(250 \mathrm{mM})$ added to all flocculating cultures to test if the cell aggregation was due to true flocculation. To quantify the flocculation ability the following modification of the procedure of Bidard et al. (1995) was used. Yeast cells were cultivated in YPD and YDC medium until late in the logarithmic growth phase. The culture of cells $(2 \mathrm{~mL})$ was pelleted by pulse-spinning and washed twice with $1 \mathrm{~mL}$ of deflocculating buffer ( $20 \mathrm{mM}$ citrate; $\mathrm{pH} 3.0$, and 5 mM EDTA). The pellet was resuspended in the deflocculating buffer at a concentration of $5 \times 10^{3}$ cells per $\mathrm{mL}$. A total of $800 \mu \mathrm{L}$ of suspended cells was added to a cuvette with $1 \mathrm{~cm}$ path length. Flocculation was initiated by the addition of $200 \mu \mathrm{L}$ of $100 \mathrm{mM}$ $\mathrm{CaCl}_{2}$. The cuvette was sealed with parafilm and inverted several times before the absorbancy at $600 \mathrm{~nm}$ was read every $30 \mathrm{~s}$ on a Ultrospec 2000 spectrophotometer (PharmaciaBiotech). A constant decrease in the absorbance reading indicated the ability to flocculate. When the absorbance reading remained more or less steady, no flocculation ability was present in the yeast strains. Laboratory control strains L016 and SY- were used in both procedures to measure flocculating potential.

Stress resistance/response: Yeast cells were cultivated until late in the logarithmic phase. Each strain $(5 \mu \mathrm{l})$ was spotted onto YPD agar plates in triplicate. The ability of these strains to survive 'heat shock' and 'cold shock' treatments was examined by placing the plates at $55^{\circ} \mathrm{C}$ and $-20^{\circ} \mathrm{C}$, respectively, for $1 \mathrm{~h}$. The plates were then placed at $30^{\circ} \mathrm{C}$ and the growth monitored after $24 \mathrm{~h}$ and $48 \mathrm{~h}$. Commercial wine yeast strains VIN13, VIN7 and N96 and the laboratory non-S. cerevisiae strains 533 and 548 were used as controls.

Extracellular enzyme activities: The various strains were tested for hydrogen sulphide production (bismuth-containing medium) and hydrolysis of compounds such as cellulose, starch, casein, xylan, lichenan, polygalacturonase, cellobiose, ß-glucan and arbutin. Yeast cells were cultivated until late in the logarithmic growth phase. Yeast cultures $(5 \mu 1)$ were spotted onto YPD agar. These YPD plates were replica plated onto media containing the above-mentioned compounds and incubated at $30^{\circ} \mathrm{C}$. Cellulose plates had to be stained with $0.5 \%$ congo red for $15 \mathrm{~min}$ and destained with $1 \mathrm{M}$ sodium chloride for $15 \mathrm{~min}$. Lichenan and B-glucan plates had to be stained with $0.5 \%$ congo red and polygalacturonase plates had to be stained with $0.1 \%$ ruthinium red. Commercial wine yeast strains VIN13, VIN7 and N96 and the laboratory non-S. cerevisiae strains 533 and 548 were used as controls.

Formation of pseudohyphae and ability to grow invasively: The method of Gimeno et al. (1992) as adapted by Lambrechts et al. (1996) was used. Yeast cells were cultivated in YPD medium until late in the logarithmic growth phase. The formation of pseudohyphae was investigated by spotting $10 \mu \mathrm{L}$ of cell culture onto two slides containing $3.9 \%$ potato dextrose agar. The slides were incubated at $30^{\circ} \mathrm{C}$ and growth was monitored under a light microscope (Reichart-Jung) after 3, 6, 9 and 12 days. All strains were photographed on the 12th day. Invasive growth was determined by spotting $5 \mu \mathrm{L}$ of cell culture onto four plates of nitrogen-limited medium ( $2 \%$ glucose, $0.17 \%$ yeast nitrogen base without amino acids and ammonium sulphate, $0.05 \mathrm{mM}$ ammonium sulphate and $2 \%$ agar). The plates were incubated at $30^{\circ} \mathrm{C}$ and washed with water after 2, 4, 6 and 12 days. Colonies that grew invasively into the medium remained on the plate, whereas those that did not were washed off. Plates were photographed on the 12th day.

\section{RESULTS AND DISCUSSION}

Climatic conditions at sites sampled: Heat summation data for the areas sampled are presented in Table 1. This table also contains data for the sites sampled by Van der Westhuizen et al. (2000a). Generally whole areas are allotted a specific heat summation category. However, this does not mean that all sites in those areas necessarily have the same classification. This point is illustrated by the two sites sampled in Malmesbury (general classification IV). Whereas site 2 is in fact classified as category IV, analysis of mean February temperatures indicated that site 1 should in fact be classified as category III. From Table 1 it is clear that Villiersdorp also has a cooler climate than the rest of the sites in the "warmer", inland region. Sites sampled by Van der Westhuizen et al. (1999) all fell into categories II or III.

Isolation of S. cerevisiae: Fermentation rates of the various samples differed appreciably. Whereas samples from Porterville (site 2) and Robertson (site 1) completed fermentation in less than 30 days, those from Slanghoek, Montagu (site 2) and RiebeekKasteel (site 1) did not ferment at all (fermentable sugar $>200$ $\mathrm{g} / \mathrm{L}$ after 80 days). This observation clearly indicates that these samples contained different yeasts. Samples from six sites, viz. Slanghoek, Robertson (site 2), Montagu (site 2), Riebeek-Kasteel (site 1), Malmesbury (site 2) and Porterville (site 1), did not contain strains of S. cerevisiae (Table 2), thus confirming that this yeast is not abundant in nature (Van Zyl \& Du Plessis, 1961; Benda, 1964; Martini et al., 1996; Van der Westhuizen et al., 2000a, b).

Chromosomal banding patterns (CHEF analysis): Electrophoretic karyotypes were determined for all 30 isolates from each of the 19 sampling sites (data not shown). Comparison of chromosomal banding patterns per sampling site revealed the presence of $30 \mathrm{~S}$. cerevisiae strains hereafter designated W1-W30 (Table 2). Direct comparison of the banding patterns of W1-W30 
TABLE 2

Number of Saccharomyces cerevisiae strains per sampling site isolated from the warmer, inland wine regions of the Western Cape of South Africa during 1997.

\begin{tabular}{|c|c|c|c|c|}
\hline Area & Isolate & $\begin{array}{l}\text { Number out of } \\
30\end{array}$ & Killer & $\%$ per strain \\
\hline Nuy & $\begin{array}{l}\text { W1 } \\
\text { W2 }\end{array}$ & $\begin{array}{r}29 \\
1\end{array}$ & - & $\begin{array}{r}96.5 \\
3.5\end{array}$ \\
\hline Rawsonville & W3 & 0 & - & 100 \\
\hline *Robertson (site 1) & $\mathrm{W} 4$ & 30 & + & 100 \\
\hline Du Toits Kloof & $\begin{array}{l}\text { W5 } \\
\text { W6 } \\
\text { W7 } \\
\text { W8 } \\
\text { W9 } \\
\end{array}$ & $\begin{array}{r}17 \\
6 \\
2 \\
2 \\
3 \\
\end{array}$ & $\begin{array}{l}+ \\
+ \\
+ \\
+ \\
+ \\
\end{array}$ & $\begin{array}{c}57 \\
20 \\
6.5 \\
6.5 \\
10 \\
\end{array}$ \\
\hline${ }^{*}$ Montagu (site 1) & $\begin{array}{l}\text { W10 } \\
\text { W11 }\end{array}$ & $\begin{array}{l}14 \\
16 \\
\end{array}$ & $\begin{array}{l}+ \\
+ \\
\end{array}$ & $\begin{array}{l}47 \\
53\end{array}$ \\
\hline Tulbagh & W12 & 30 & - & 100 \\
\hline *Riebeeck-Kasteel (site 2) & $\begin{array}{l}\text { W13 } \\
\text { W14 } \\
\text { W15 } \\
\text { W16 } \\
\text { W17 } \\
\text { W18 } \\
\text { W19 }\end{array}$ & $\begin{array}{r}13 \\
6 \\
3 \\
4 \\
2 \\
1 \\
1\end{array}$ & $\begin{array}{l}- \\
- \\
+ \\
+ \\
+ \\
- \\
+\end{array}$ & $\begin{array}{r}43 \\
20 \\
10 \\
13.5 \\
6.5 \\
3.5 \\
3.5\end{array}$ \\
\hline *Malmesbury (site 1) & W20 & 30 & - & 100 \\
\hline Wolseley & $\begin{array}{l}\text { W21 } \\
\text { W22 } \\
\text { W23 }\end{array}$ & $\begin{array}{r}22 \\
5 \\
3\end{array}$ & $\begin{array}{l}+ \\
- \\
-\end{array}$ & $\begin{array}{l}73 \\
17 \\
10\end{array}$ \\
\hline Bonnievale & $\begin{array}{l}\text { W24 } \\
\text { W25 } \\
\text { W26 } \\
\text { W27 }\end{array}$ & $\begin{array}{r}23 \\
5 \\
1 \\
1\end{array}$ & $\begin{array}{l}+ \\
- \\
+ \\
-\end{array}$ & $\begin{array}{c}76 \\
17 \\
3.5 \\
3.5\end{array}$ \\
\hline${ }^{*}$ Porterville (site 2) & $\mathrm{W} 28$ & 30 & - & 100 \\
\hline Villiersdorp & W29 & 30 & + & 100 \\
\hline Ashton & W30 & 30 & + & 100 \\
\hline
\end{tabular}

* = S. cerevisiae could only be isolated from these sites in the respective areas.

(Fig. 1) revealed that these 30 yeasts represented 21 unique strains of S. cerevisiae (Table 3). Haploid strains of S. cerevisiae generally contain 16 chromosomes ranging in size from approximately 200 to $2200 \mathrm{~kb}$ (Mortimer et al., 1989; Cherry et al., 1997). The chromosome number of strains W1-W30 varied from 11 to 16.

Most of these sites did not exhibit a great deal of genetic variation, with one strain completely dominating at seven of the 13 sites. The genetic diversity varied most in the Riebeek-Kasteel (seven strains) and Du Toits Kloof areas (five strains) (Table 2). The number of strains per site was thus considerably less than that recorded for the coastal areas of the Western Cape during 1995 (Van der Westhuizen et al., 2000a). In that study the number of strains varied from two to 15 .

The lower number of different $S$. cerevisiae strains recorded in this study (30 at 13 of 19 sites) (Table 2) in comparison to that found in the coastal areas (51 at eight of the 13 sites) (Van der
Westhuizen et al., 2000a) could be attributed to a number of factors. The number of sites (samples) not containing any S. cerevisiae is similar (68.4\% in this study and $61.5 \%)$. That many grape samples do not contain any $S$. cerevisiae at all is a well-documented fact (Vaughan-Martini \& Martini, 1995; Török et al., 1996). It is also known that vineyard yeast microflora vary from year to year and terrain to terrain (Schütz \& Gaffner, 1994). It is therefore possible that this relatively large difference in the number of yeasts recovered could be ascribed to the different vintages being compared (1997 versus 1995) and/or the appreciable differences between the climates of the different study areas (Table 1). However, the numbers of yeasts recovered at the coastal sites during 1997 were dramatically lower than those recovered during 1995 (Van der Westhuizen et al., 2000b). These authors coupled the almost complete absence of S. cerevisiae in the 1997 samples to the severe outbreak of fungal diseases and consequent heavy application of chemical sprays during the growing season. From the rainfall data presented in 

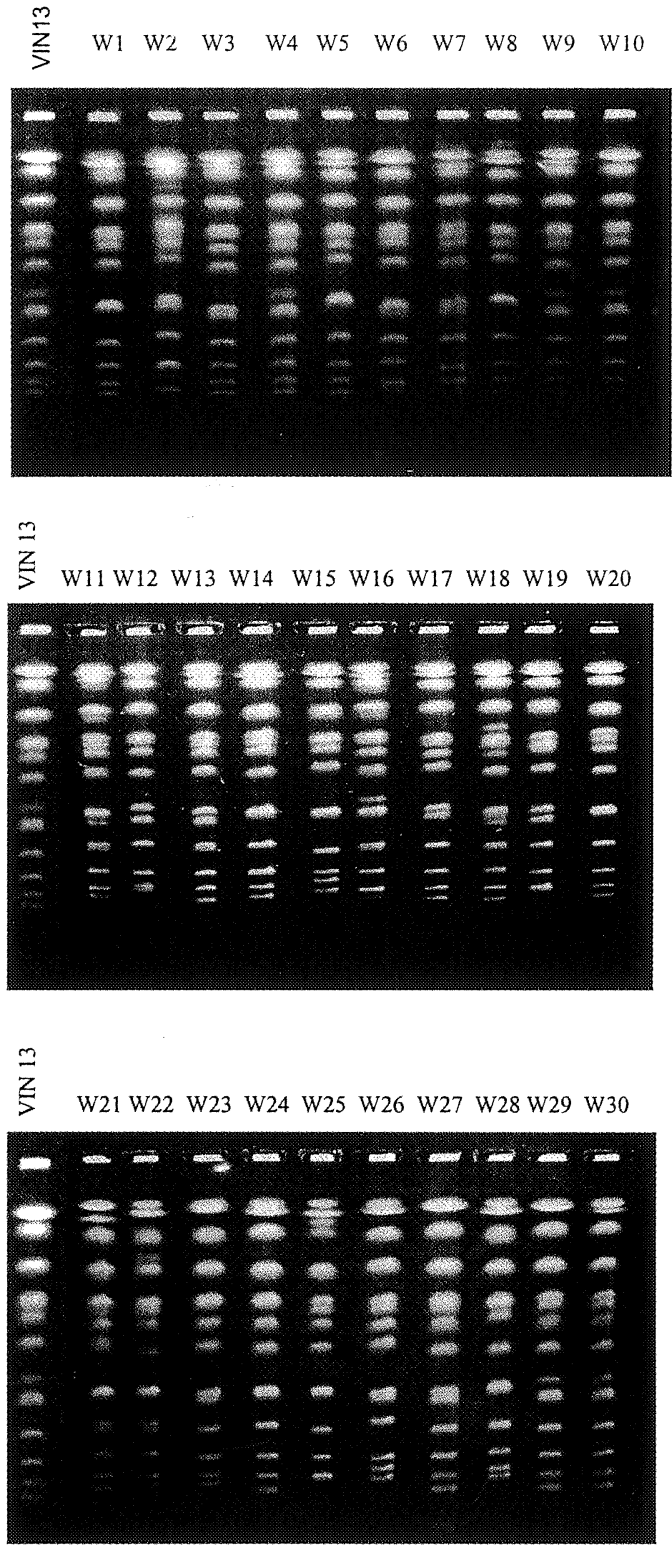

FIGURE 1

Electrophoretic karyotypes of the Saccharomyces cerevisiae strains isolated from the warmer, inland wine regions of the Western Cape of South Africa during 1997; ControlCommercial strain VIN13 (a) Strains W1-W10, (b) Strains W11-W12, and (c) Strians W21-W30.

Table 4 it is clear that in general the areas sampled here during 1997 also experienced a wetter than normal growing and pre-harvest period. However, considering the numbers of $S$. cerevisiae recovered, it cannot be concluded that the relatively low numbers of yeasts were the direct result of the higher rainfall and consequent increased application of chemical sprays.

Five of the recovered yeast strains (W4, W9, W10, W29 and W30) had chromosomal banding patterns similar to VIN 13 (Fig. 1). Comparing the chromosomal banding patterns of W1-W30 to the banding patterns collected in the Nietvoorbij database confirmed that these five strains did represent recovery
W1 W2 W3 W4 W5 W6 W7 W8 W9 W10

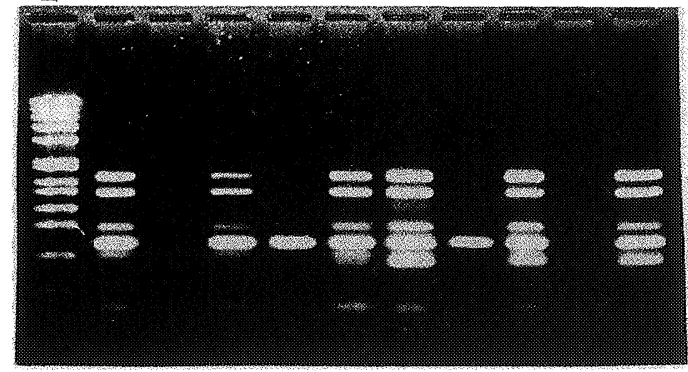

(a)

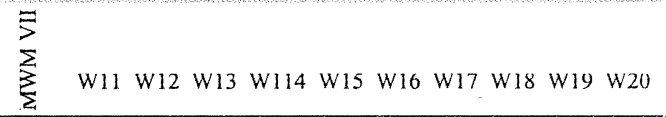

(b)
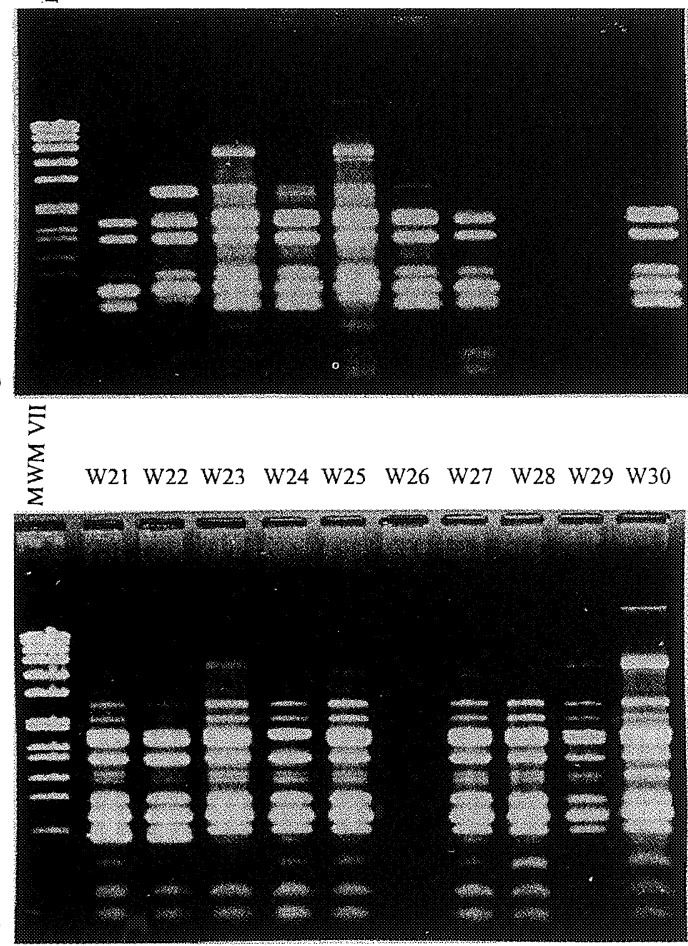

FIGURE 2

Amplified DNA patterns obtained with different $S$. cerevisiae yeast strains in PCR by using primer OPC-09 (5'-CTCACCGTCC-3'): (a) W1-W10; (b) W11-W20; and (c) W21-W30. Molecular weight marker VII (Boehringer Mannheim) was used as a standard.

of VIN 13 from nature. From this scan of the database it was also clear that none of the indigenous strains recovered in this study occurred in the coastal areas studied by Van der Westhuizen et al. (2000a,b) (data not shown). This implies that the genetic make-up of indigenous $S$. cerevisiae in the inland and coastal areas of the Western Cape is completely different. In addition, no single indigenous strain occurred in all the areas sampled.

RAPD-PCR banding patterns: No banding patterns were obtained for strains W9, W18 and W26, irrespective of which of the five primers was used (Table 3). It can be hypothesised that strains which did not exhibit any bands had exonucleases present 
TABLE 3

Characterisation of strains W1-W30 using molecular, physiological, biochemical and biological techniques.

\begin{tabular}{|c|c|c|c|c|c|c|c|c|c|c|}
\hline 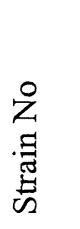 & 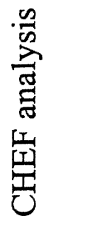 & 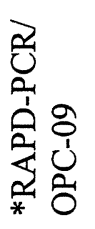 & 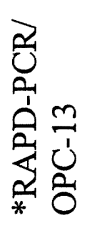 & 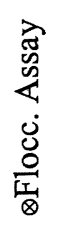 & 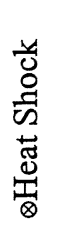 & 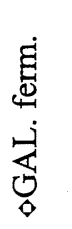 & 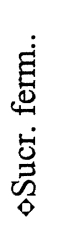 & 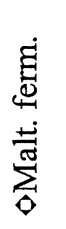 & 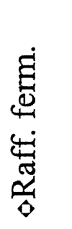 & 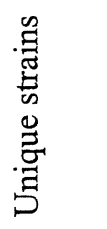 \\
\hline W1 & $\mathrm{C} 1$ & $\mathrm{R} 1$ & $\mathrm{P} 1$ & - & + & - & + & - & + & WK1 \\
\hline W2 & $\mathrm{C} 2$ & - & $\mathrm{P} 2$ & - & $\mathrm{V}$ & - & + & - & + & WK5 \\
\hline W3 & $\mathrm{C} 3$ & $\mathrm{R} 1$ & - & - & $\mathrm{V}$ & + & + & + & + & WK6 \\
\hline W4 & $\mathrm{C} 4$ & $\mathrm{R} 2$ & - & - & + & + & + & + & + & WK9 \\
\hline W5 & $\mathrm{C} 1$ & $\mathrm{R} 1$ & $\mathrm{P} 1$ & - & + & + & + & - & + & WK2 \\
\hline W6 & C5 & $\mathrm{R} 3$ & P3 & - & + & + & + & - & + & WK14 \\
\hline W7 & C6 & $\mathrm{R} 2$ & - & - & + & + & + & + & + & WK15 \\
\hline W8 & $\mathrm{C} 7$ & $\mathrm{R} 3$ & P3 & - & $\mathrm{V}$ & + & + & - & + & WK16 \\
\hline W9 & $\mathrm{C} 4$ & - & - & - & $\mathrm{V}$ & + & + & + & + & WK10 \\
\hline W10 & $\mathrm{C} 4$ & $\mathrm{R} 3$ & P3 & - & + & + & + & + & + & WK 11 \\
\hline W11 & $\mathrm{C} 8$ & $\mathrm{R} 1$ & - & - & $\mathrm{V}$ & + & + & + & + & WK17 \\
\hline W12 & C9 & $\mathrm{R} 4$ & P3 & + & + & + & + & + & + & WK 18 \\
\hline W13 & $\mathrm{C} 3$ & R5 & $\mathrm{P} 4$ & - & + & + & + & + & + & WK7 \\
\hline W14 & $\mathrm{Cl}$ & R6 & P5 & - & + & + & + & + & + & WK3 \\
\hline W15 & $\mathrm{C} 10$ & R7 & P5 & - & + & + & + & + & - & WK19 \\
\hline W16 & $\mathrm{C} 11$ & R6 & P6 & - & $\mathrm{V}$ & + & + & + & + & WK20 \\
\hline W17 & $\mathrm{C} 12$ & $\mathrm{R} 3$ & $\mathrm{P} 7$ & - & $\mathrm{V}$ & + & + & - & + & WK21 \\
\hline W18 & $\mathrm{C} 13$ & - & - & - & + & + & + & + & + & WK22 \\
\hline W19 & $\mathrm{C} 14$ & - & $\mathrm{P} 4$ & - & + & + & + & + & + & WK23 \\
\hline W20 & $\mathrm{C} 1$ & R3 & $\mathrm{P} 4$ & - & + & + & + & + & + & WK4 \\
\hline W21 & $\mathrm{C} 15$ & $\mathrm{R} 8$ & $\mathrm{P} 4$ & - & + & + & + & + & + & WK24 \\
\hline W22 & $\mathrm{C} 16$ & $\mathrm{R} 8$ & P8 & - & + & + & + & + & + & WK25 \\
\hline W23 & $\mathrm{C} 17$ & R9 & $\mathrm{P} 4$ & - & $\mathrm{V}$ & + & + & + & + & WK26 \\
\hline W24 & $\mathrm{C} 18$ & $\mathrm{R} 10$ & P8 & - & - & + & + & + & + & WK27 \\
\hline W25 & $\mathrm{C} 19$ & R9 & P4 & - & + & + & + & + & + & WK28 \\
\hline W26 & $\mathrm{C} 20$ & - & - & - & + & + & + & - & + & WK29 \\
\hline W27 & $\mathrm{C} 3$ & R9 & - & - & $\mathrm{V}$ & + & + & + & + & WK8 \\
\hline W28 & $\mathrm{C} 21$ & R9 & - & - & + & + & - & + & - & WK30 \\
\hline W29 & $\mathrm{C} 4$ & R11 & - & - & $\mathrm{V}$ & + & + & + & + & WK 12 \\
\hline W30 & $\mathrm{C} 4$ & $\mathrm{R} 12$ & - & - & $\mathrm{V}$ & + & + & + & + & WK13 \\
\hline
\end{tabular}

*: -= no bands obtained;

$\otimes:-=$ negative result; $+=$ positive result; $V=$ Variable result.

$\circ:-=$ negative result; $+=$ positive result.

which degraded the DNA at an extremely rapid rate. Distinct banding pattern differences were only obtained when using primers OPC-09 and OPC-13. While 17 strains produced banding patterns with both primers, others (10) gave banding patterns with only one of the primers. Banding patterns for OPC-09 are depicted in Fig. 2. From this figure it is clear that a considerable number of shared bands were generated for the different strains.

Based solely on CHEF karyotyping, it appeared as if strains W4, W9, W10, W29 and W30 represented recoveries of the commercial strain VIN13. From Table 3 it is clear that this was not so and that each of these isolates represented a different yeast strain (data for VIN13 not shown). This result indicates that no commercial yeasts were recovered from nature in this study. In contrast, Van der Westhuizen et al. (2000a, b) recovered commercial yeasts at a number of sites during 1995 to 1997, but not during 1998.

It was not possible to distinguish between the following groups of strains when using the OPC-09 primer: W1, W3, W5 and W11; W4 and W7; W6, W8, W10, W17 and W20; W14 and W16; W21 and W22; W23, W25, W27 and W28. When using primer OP-13, however, it was possible to distinguish between $69,7 \%$ of the various strain combinations represented by these groups (Table 
TABLE 4

Monthly rainfall (in mm) in the Ashton, Bonnievale, Du Toits Kloof, Malmesbury, Montagu, Nuy, Porterville, Rawsonville, Riebeek-

Kasteel, Robertson, Slanghoek, Tulbagh, Villiersdorp and Wolseley areas.

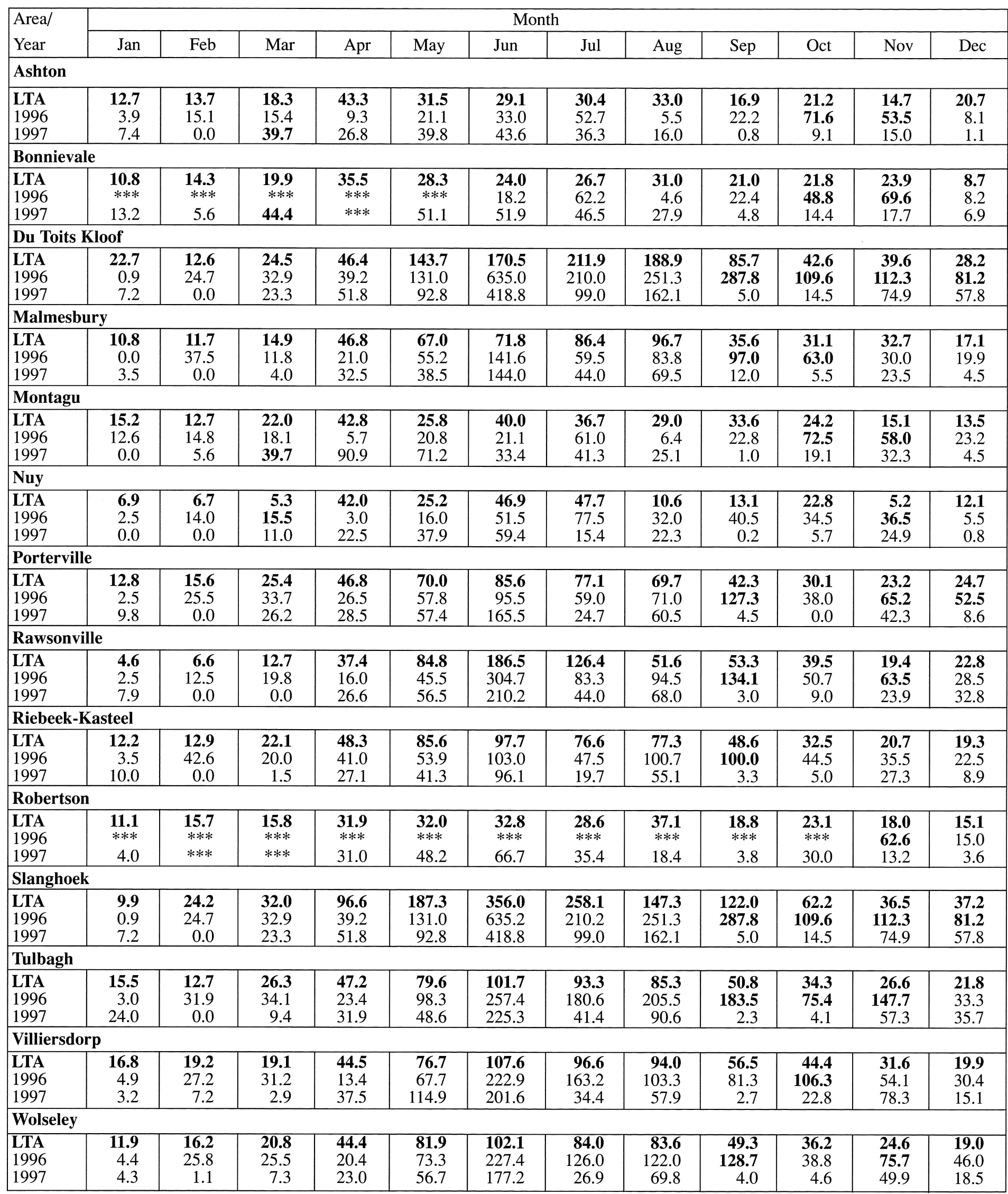

$* * *=$ No data available. 
3). No single primer was able to separate all of the $S$. cerevisiae strains under study. However, when combining RAPD-PCR data and CHEF DNA analysis, it was possible to differentiate between all strains except W1 and W5 (Table 3), thus indicating that the recovered yeasts represented 29 distinct strains of $S$. cerevisiae.

Results indicated that reactions made in the same run give identical banding patterns, but when the same reactions were run on a different day, no bands or bands of a different intensity were obtained. The RAPD-PCR technique is a rapid and simple process, based on the amplification of genomic DNA with single primers of arbitrary nucleotide sequence. A further advantage of this technique is that no specific knowledge of the genome to be amplified is needed. A few problems, however, are frequently cited when this technique is used. One is that the level of polymorphism detected is relatively low, as amplification patterns of the strains are regularly quite similar. Another recurring problem is the poor reproducibility of some of the bands. The effect of many variables in the reaction that contribute to these problems has been studied by MacPherson et al. (1993). Some of these factors are: different thermal cyclers used; the specific type and brand of DNA-polymerase; the concentration of DNA and primers; and the composition of the reaction buffer. It is therefore imperative to standardise reaction parameters and perform replications of the same reaction on different days. Although this technique can prove invaluable as a corroborating technique, because of the relative cost- and time-effectiveness, results obtained emphasised the findings of other research that electrophoretic karyotyping is more reliable and repeatable (Van der Westhuizen et al., 1999).

All physiological and biochemical tests were performed on S. cerevisiae strains W1-W30 and T1-T51 (Van der Westhuizen et al., 2000a).

Fermentation ability: As expected, all yeast strains were able to utilise glucose as a carbon source (Table 5). Most of the strains could also ferment the rest of the sugars tested with similar results obtained for sucrose and raffinose: $97 \%$ and $97 \%$; $94 \%$ and $93 \%$ for strains T1-T51 and W1-W30, respectively. Galactose fermentation by $S$. cerevisiae strains is often variable (Kurtzman $\&$ Fell, 1998). Eighty-two percent of strains T1-T51 and 93\% of strains W1-W30 were able to ferment this sugar. The most apparent difference was observed when only $77 \%$ of strains W1-W30 were able to ferment maltose, in contrast to $90 \%$ of strains T1-T51. From the results obtained it was obvious that, in general, no significant differences could be observed in the way the strains W1-W30 and T1-T51 fermented the carbon sources. However, the fact that W1 was galactose negative and W5 was galactose positive (Table 3 ) indicated that these strains were not the same.

The 30 different yeasts originally identified when comparing biodiversity per sampling site in fact represent 30 unique strains of $S$. cerevisiae [WK1-WK30 (Table 3)]. Each of the sites sampled therefore appears to have its own unique wine yeast community. The validity of this assumption will have to be confirmed by more extensive sampling. If confirmed then localisation of yeast communities would represent a significant difference between the yeast microflora of the inland and coastal areas (Van der Westhuizen et al., 2000a, b) of the Western Cape region.
TABLE 5

Carbon source utilisation of strains W1-W30 And T1-T51*: Summary of date**.

\begin{tabular}{|l|c|c|}
\hline $\begin{array}{l}\text { Sugars } \\
\text { tested }\end{array}$ & $\begin{array}{c}\text { Cooler area } \\
\text { (t1-t51) }\end{array}$ & $\begin{array}{c}\text { Warmer areas } \\
\text { (w1-w30) }\end{array}$ \\
\hline Glucose & $100 \%=+$ & $100 \%=+$ \\
Galactose & $82 \%=+$ & $93 \%=+$ \\
Sucrose & $18 \%=-$ & $7 \%=-$ \\
& $97 \%=+$ & $97 \%=+$ \\
Maltose & $3 \%=-$ & $3 \%=-$ \\
& $90 \%=+$ & $77 \%=+$ \\
Raffinose & $10 \%=-$ & $23 \%=-$ \\
& $94 \%=+$ & $93 \%=+$ \\
& $6 \%=-$ & $7 \%=-$ \\
\hline
\end{tabular}

* Isolated by Van der Westhuizen et al. (2000a).

** Individual results for strains W1-W30 presented in Table 3.

Flocculation assay: Three test media, namely, YPD, YPGE and YDC with $0 \%$ and $1 \% \mathrm{CaCl}_{2}$, were used to test the ability of strains to flocculate. This procedure was done in duplicate and due to the extensive data obtained the results are not shown. Only strain W12 flocculated consistently. None of the other strains exhibited flocculation ability when grown in YPD medium $(0 \%$ and $\left.1 \% \mathrm{CaCl}_{2}\right)$ and YPGE and YDC medium $\left(0 \% \mathrm{CaCl}_{2}\right)$. However, when cultured in YPGE medium containing $1 \% \mathrm{CaCl}_{2}$, $17 \%$ of strains $\mathrm{W} 1-\mathrm{W} 30$ and $27 \%$ of T1-T51 were able to flocculate. When cultured in YDC medium containing $1 \% \mathrm{CaCl}_{2}$, W12 and 12\% of T1-T51 flocculated. To determine if this was true flocculation or cell aggregation EDTA $(250 \mathrm{mM})$, which removes the flocculation stimulating $\mathrm{CaCl}_{2}$, from the growth medium, was added to the cultures. After approximately 5 min no flocculation particles could be observed in the test media containing W12, which implied that this is a true flocculating strain. All the rest of the strains exhibited a variable result, i.e. after approximately $5 \mathrm{~min}$ the test medium went cloudy, but small cell particles could still be observed.

A flocculation assay based on the procedure of Bidard et al. (1995) was then carried out to verify the results obtained by testing the strains in the various media. Only strain W12 again exhibited any or strong flocculation potential when compared to the flocculation positive controls (laboratory strains SY- and L016). Clearly only W12 was a true flocculating strain. The apparently positive results of the other strains could have been due to cell aggregation.

Stress resistance/response: All the strains grew $24 \mathrm{~h}$ after exposure to $-20^{\circ} \mathrm{C}$ (results not shown), while no growth by any of the yeast strains was observed $24 \mathrm{~h}$ after exposure to $55^{\circ} \mathrm{C}$. However, $48 \mathrm{~h}$ after exposure to $55^{\circ} \mathrm{C}: 60 \%$ and $50 \%$ growth; $3 \%$ 
and $25 \%$ no growth; and $37 \%$ and $25 \%$ variable growth (small clumps of colonies), was exhibited by yeast strains W1-W30 and T1-T51, respectively, as shown in Fig. 3. No distinct differences could be observed between strains W1-W30 and T1-T51. However, the strains isolated in the warmer, inland regions did show a slightly better ability to survive the excessive heat treatment, as expected.

Extracellular enzyme activities: All the strains exhibited identical results in the hydrolysis of the various compounds tested, i.e. all strains were cellulose negative, starch negative, casein negative, xylan negative, lichenan negative, poligalacturonase negative, cellobiose positve, ß-glucan negative and arbutin positive (results not shown). The ability of these

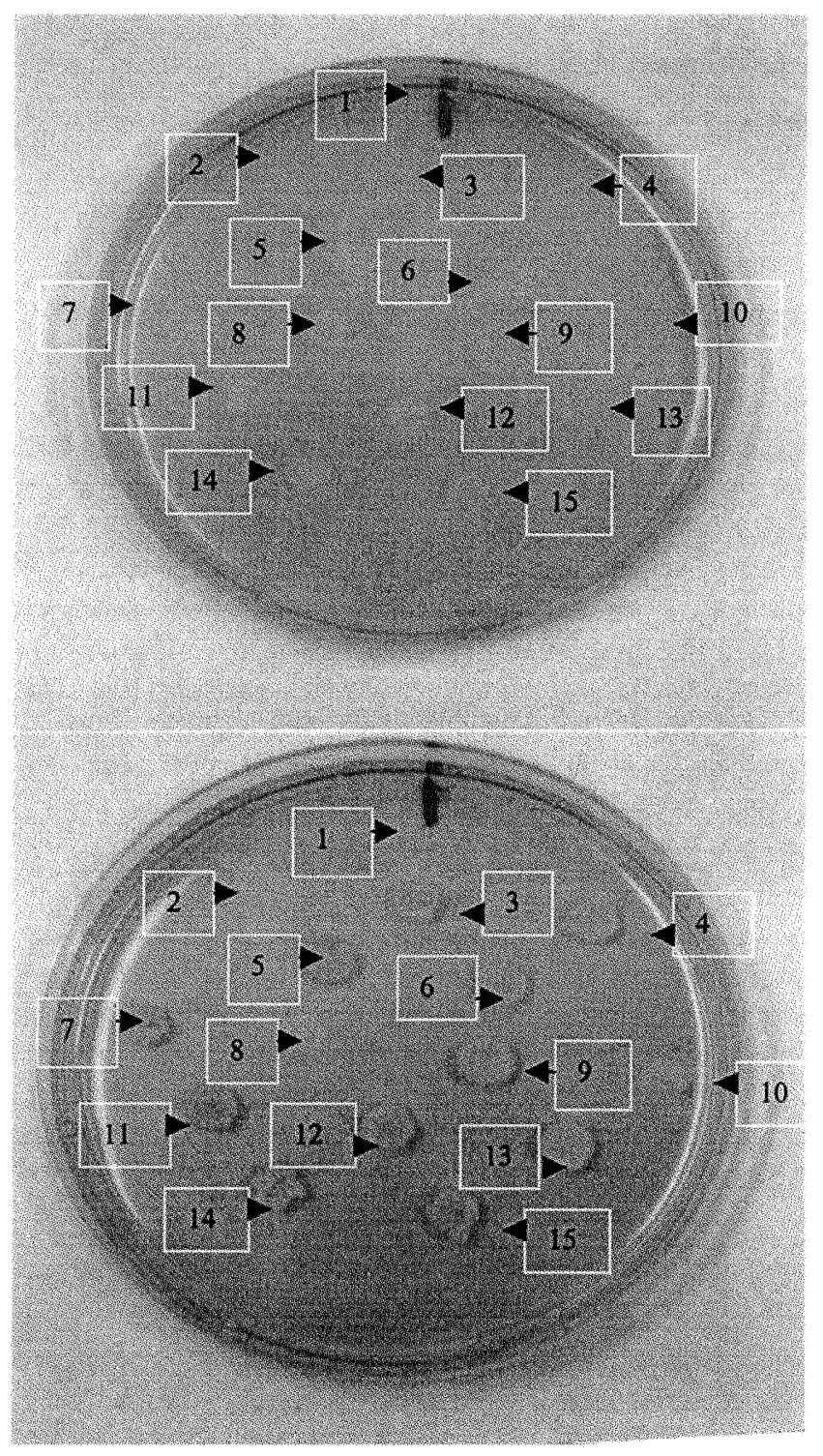

FIGURE 3

The ability of strains T1-T15 [isolated by Van der Westhuizen et al., 2000a] from the cooler, coastal wine regions of the Western Cape in South Africa to survive exposure to $55^{\circ} \mathrm{C}$ : (a) after $24 \mathrm{~h}$; (b) after $48 \mathrm{~h}$. strains to produce hydrogen sulphide (Fig. 4) was also similar (Table 6). Clearly geographic area of isolation played no role in the ability of the yeasts in this regard.

Investigation into possible survival mechanisms of S. cerevisiae: Formation of pseudohyphae and ability to grow invasively: Extensive invasive growth and pseudohyphal differentiation were observed when the $S$. cerevisiae strains were grown on nitrogen-limiting medium and potato dextrose agar, respectively, as shown in Table 7 and Figs. 5 and 6. The procedure to examine pseudohyphal growth of strains W1-W30 and T1-T51 was repeated three times and of these strains $80 \%$ and $69 \%$, respectively, could consistently form pseudohyphae.

The procedure to examine invasive growth was also repeated three times and of these strains, $40 \%$ (W1-W30) and $47 \%$ (T1-T51) could consistently grow invasively into the agar medium, while $20 \%$ and $12 \%$, respectively, could not grow invasively. A variable result was obtained for $40 \%$ and $41 \%$ of strains W1-W30 and T1-T51, respectively. A variable result generally indicated that these strains could not consistently grow invasively into the test medium. Their results constantly changed from positive (slight growth observed) to negative and vice versa. No distinct differences were observed in the ability of the strains isolated from the warmer, inland and cooler, coastal wine regions to form pseudohyphae and grow invasively.

From the above, it is clear that a high percentage of the yeast strains from both the inland and coastal areas can grow invasively and form pseudohyphae. These mechanisms could therefore be a factor in this organism's survival strategy in the vineyard and on the winery equipment from one season to the next.

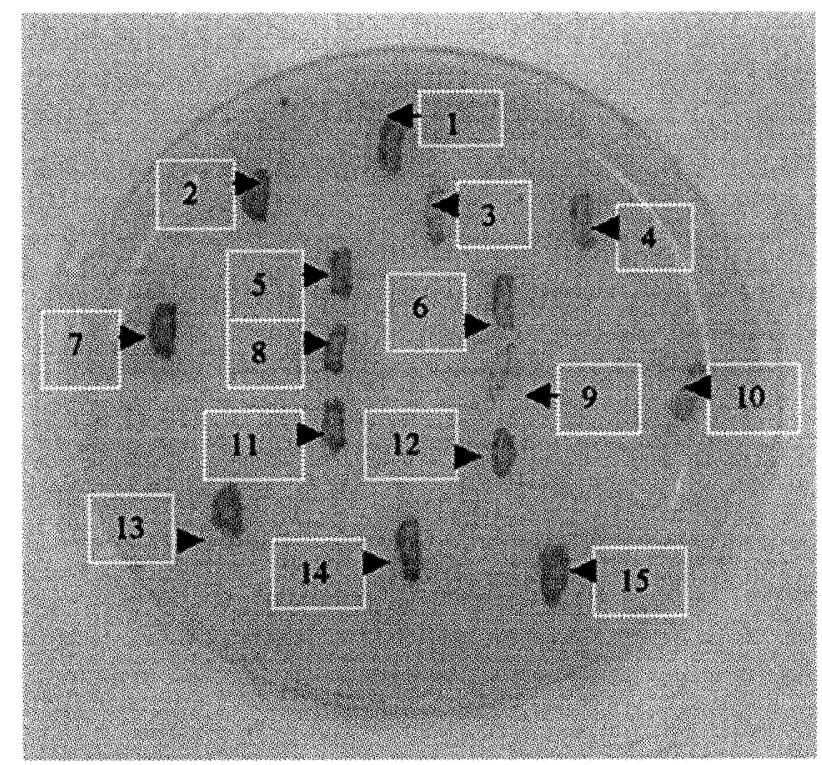

FIGURE 4

Production of hydrogen sulphide by strains W1-W15, isolated from the warmer, inland wine regions of the Western Cape in South Africa. 
TABLE 6

Production of hydrogen sulphide by strains W1-W30 and T1-T51 isolated in the warmer, inland and cooler, coastal wine regions of the Western Cape in South Africa, respectively.

\begin{tabular}{|c|c|c|c|c|c|}
\hline No & $\begin{array}{l}\text { Hydrogen } \\
\text { Sulphide } \\
\text { production }\end{array}$ & Strain & $\begin{array}{l}\text { Hydrogen } \\
\text { sulphide } \\
\text { production }\end{array}$ & Strain & $\begin{array}{l}\text { Hydrogen } \\
\text { sulphide } \\
\text { production }\end{array}$ \\
\hline $\mathrm{W} 1$ & 3 & $\mathrm{~T} 1$ & 3 & T31 & 3 \\
\hline W2 & 3 & $\mathrm{~T} 2$ & 3 & T32 & 3 \\
\hline W3 & 3 & $\mathrm{~T} 3$ & 1 & T33 & 2 \\
\hline W4 & 2 & $\mathrm{~T} 4$ & 2 & $\mathrm{~T} 34$ & 2 \\
\hline W5 & 3 & T5 & 1 & T35 & 2 \\
\hline W6 & 3 & T6 & 1 & T36 & 2 \\
\hline W7 & 3 & $\mathrm{~T} 7$ & 2 & T37 & 3 \\
\hline W8 & 3 & $\mathrm{~T} 8$ & 3 & T38 & 2 \\
\hline W9 & 1 & T9 & 3 & T39 & 3 \\
\hline W10 & 2 & $\mathrm{~T} 10$ & 3 & $\mathrm{~T} 40$ & 3 \\
\hline W11 & 3 & T11 & 2 & $\mathrm{~T} 41$ & 2 \\
\hline W12 & 3 & $\mathrm{~T} 12$ & 1 & $\mathrm{~T} 42$ & 1 \\
\hline W13 & 3 & $\mathrm{~T} 13$ & 2 & $\mathrm{~T} 43$ & 3 \\
\hline W14 & 3 & T14 & 2 & $\mathrm{~T} 44$ & 3 \\
\hline W15 & 3 & $\mathrm{~T} 15$ & 3 & $\mathrm{~T} 45$ & 3 \\
\hline W16 & 3 & $\mathrm{~T} 16$ & 3 & $\mathrm{~T} 46$ & 3 \\
\hline W17 & 3 & T17 & 3 & $\mathrm{~T} 47$ & 3 \\
\hline W18 & 3 & $\mathrm{~T} 18$ & 2 & $\mathrm{~T} 48$ & 3 \\
\hline W19 & 3 & T19 & 3 & $\mathrm{~T} 49$ & 3 \\
\hline W20 & 2 & $\mathrm{~T} 20$ & 2 & $\mathrm{~T} 50$ & 3 \\
\hline W21 & 2 & $\mathrm{~T} 21$ & 2 & T51 & 3 \\
\hline W22 & 3 & $\mathrm{~T} 22$ & 3 & & \\
\hline W23 & 3 & $\mathrm{~T} 23$ & 2 & $\otimes$ VIN13 & 3 \\
\hline W24 & 3 & $\mathrm{~T} 24$ & 2 & $\otimes$ VIN7 & 3 \\
\hline W25 & 3 & $\mathrm{~T} 25$ & 3 & $\otimes$ N96 & 3 \\
\hline W26 & 3 & $\mathrm{~T} 26$ & 2 & *533 & 3 \\
\hline W27 & 1 & $\mathrm{~T} 27$ & 3 & $* 548$ & 3 \\
\hline W28 & 2 & $\mathrm{~T} 28$ & 3 & & \\
\hline W29 & 2 & T29 & 3 & & \\
\hline W30 & 2 & T30 & 3 & & \\
\hline
\end{tabular}

$0=$ white (no hydrogen sulphide production); 5 = black (excessive hydrogen sulphide production)

$\otimes=$ Commercial control strains used; * = Non-Saccharomyces laboratory control strains used.

- Isolated by Van der Westhuizen et al. (2000a). 
TABLE 7

The ability of S. cerevisiae yeast strains W1-W30 and T1-T51, isolated from the warmer, inland and cooler, coastal regions of the Western Cape in South Africa, to form pseudohyphae and grow invasively.

\begin{tabular}{|c|c|c|c|c|c|c|c|c|c|c|c|c|c|c|}
\hline 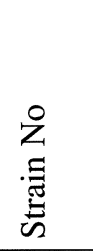 & 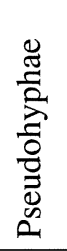 & 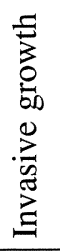 & 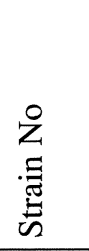 & 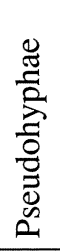 & 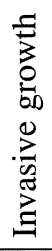 & 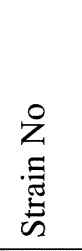 & 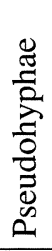 & 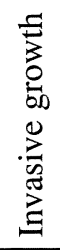 & $\begin{array}{l}\stackrel{0}{z} \\
\stackrel{\Xi}{\pi} \\
\stackrel{\Xi}{5}\end{array}$ & 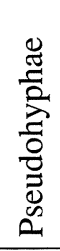 & 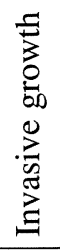 & 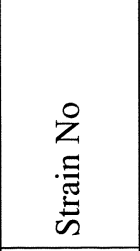 & 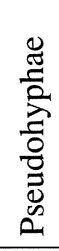 & 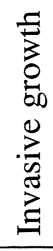 \\
\hline W1 & + & + & W21 & - & - & T10 & + & + & $\mathrm{T} 30$ & + & + & T50 & + & + \\
\hline W2 & - & - & W22 & + & V & $\mathrm{T} 11$ & + & V & $\mathrm{T} 31$ & + & V & $\mathrm{T} 51$ & + & + \\
\hline W3 & + & + & W23 & + & $\mathrm{V}$ & $\mathrm{T} 12$ & - & V & T32 & - & - & & & \\
\hline W4 & + & V & W24 & + & $\mathrm{V}$ & $\mathrm{T} 13$ & + & V & $\mathrm{T} 33$ & - & - & $\otimes$ VIN13 & + & V \\
\hline W5 & + & - & W25 & + & + & T14 & - & V & T34 & - & V & $\otimes$ VIN7 & - & $\mathrm{V}$ \\
\hline W6 & + & + & W26 & + & + & $\mathrm{T} 15$ & - . & V & T35 & - & - & $\otimes \mathrm{N} 96$ & - & $\mathrm{V}$ \\
\hline W7 & + & + & W27 & + & $\mathrm{V}$ & T16 & + & V & T36 & - & - & $* 533$ & + & + \\
\hline W8 & + & - & W28 & + & V & $\mathrm{T} 17$ & + & + & T37 & + & + & $* 548$ & - & + \\
\hline W9 & + & V & W29 & + & + & $\mathrm{T} 18$ & + & V & T38 & - & - & & & \\
\hline W10 & + & V & W30 & + & + & T19 & + & V & T39 & - & V & & & \\
\hline W11 & + & V & & & & $\mathrm{T} 20$ & + & + & $\mathrm{T} 40$ & + & + & & & \\
\hline W12 & - & V & $\mathrm{T} 1$ & + & + & $\mathrm{T} 21$ & + & + & $\mathrm{T} 41$ & - & - & & & \\
\hline W13 & - & V & $\mathrm{T} 2$ & + & + & $\mathrm{T} 22$ & + & + & $\mathrm{T} 42$ & - & V & & & \\
\hline W14 & + & + & $\mathrm{T} 3$ & + & + & $\mathrm{T} 23$ & + & + & $\mathrm{T} 43$ & + & + & & & \\
\hline W15 & + & + & $\mathrm{T} 4$ & + & $\mathrm{V}$ & $\mathrm{T} 24$ & + & + & $\mathrm{T} 44$ & + & + & & & \\
\hline W16 & - & - & $\mathrm{T} 5$ & - & V & $\mathrm{T} 25$ & - & V & $\mathrm{T} 45$ & + & + & & & \\
\hline W17 & - & - & T6 & - & $\mathrm{V}$ & $\mathrm{T} 26$ & + & + & $\mathrm{T} 46$ & + & + & & & \\
\hline W18 & + & V & T7 & - & $\mathrm{V}$ & T27 & + & + & T47 & + & + & & & \\
\hline W19 & + & + & $\mathrm{T} 8$ & + & V & $\mathrm{T} 28$ & + & V & $\mathrm{T} 48$ & + & + & & & \\
\hline W20 & + & + & T9 & - & V & T29 & + & V & $\mathrm{T} 49$ & + & + & & & \\
\hline
\end{tabular}

\footnotetext{
$+\quad=$ Positive result.

- $=$ Negative result.

$\mathrm{V}=$ Variable result.
}

$\otimes=$ Commercial control strains used.

* = Non-Saccharomyces laboratory control strains used.

= Isolated by Van der Westhuizen et al. (2000a). 


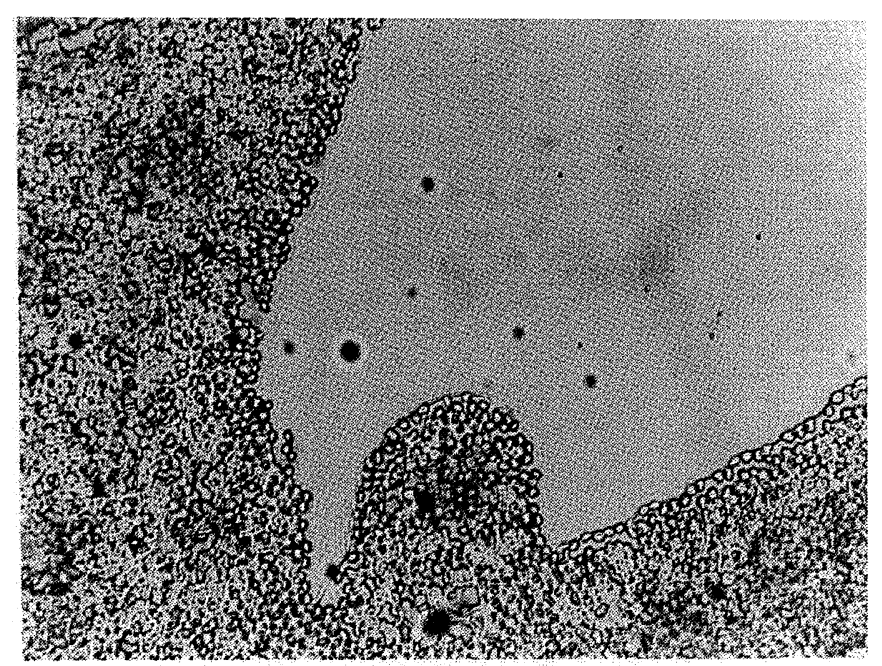

(a)

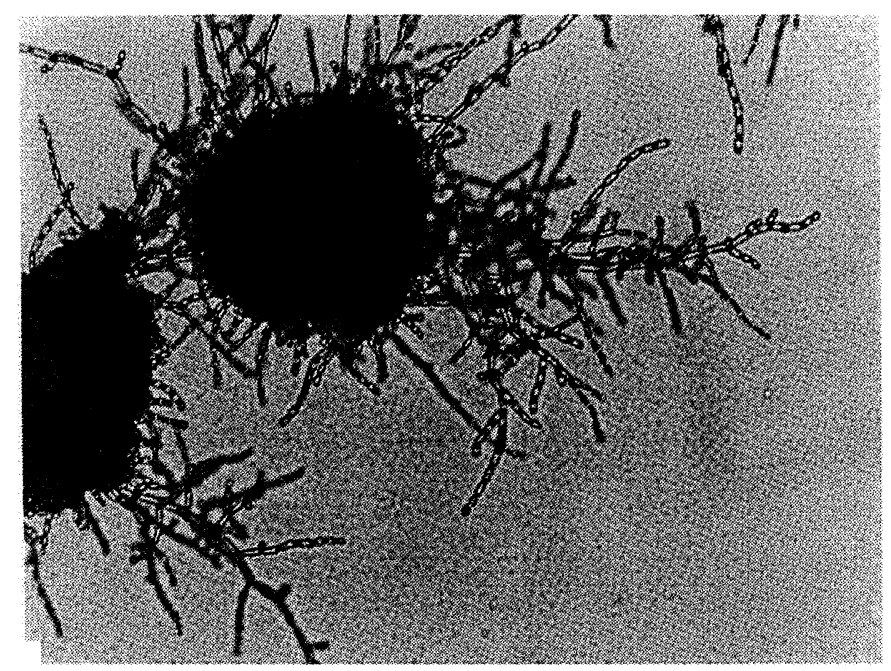

(b)

FIGURE 5

The ability of strains isolated from the warmer, inland wine regions of the Western Cape in South Africa to: (a) not demonstrate pseudohyphae formation (W2); and (b) demonstrate pseudohyphae formation (W1).

\section{GENERAL DISCUSSION}

Indigenous populations of $S$. cerevisiae in the inland areas clearly differ from those recovered in the coastal areas of the Western Cape region. The potential benefits of our yeast selection and breeding programme will therefore be boosted by sampling in as many areas/regions as possible. If further study confirms that each of the areas sampled in this study has a unique $S$. cerevisiae community, those yeasts will be useful in developing strains that will enhance the specific character of the wines from the individual areas.

While it is often possible to distinguish between yeasts by applying a single technique, unambiguous characterisation usually requires a number of techniques. In this study it was

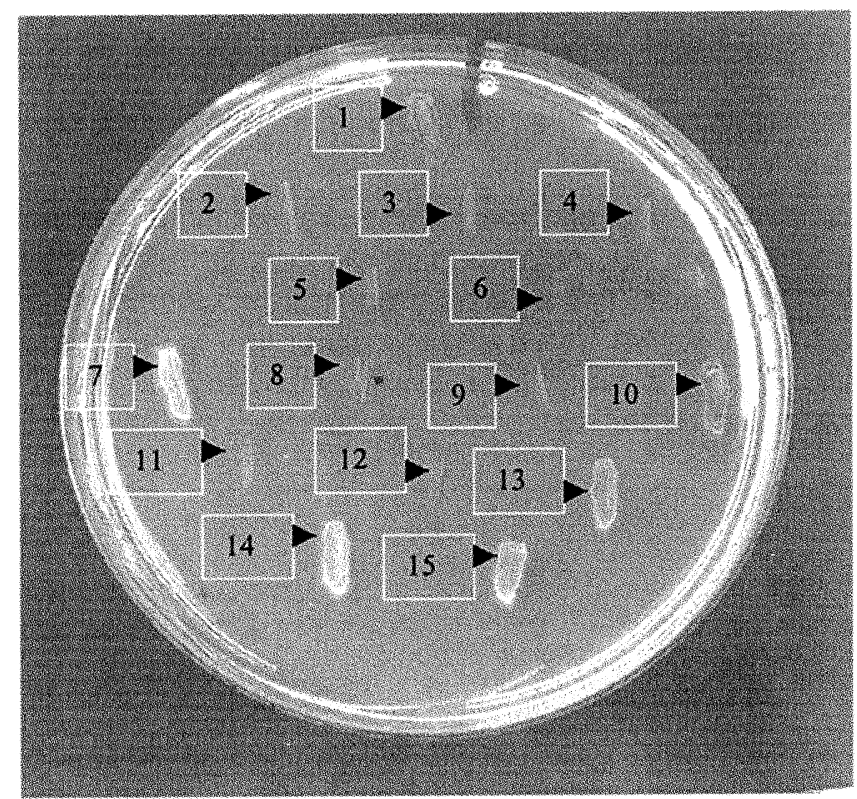

\section{FIGURE 6}

The ability of the yeast strains T31-T45 [isolated by Van der Westhuizen et al., 2000a] from the cooler, coastal wine regions of the Western Cape in South Africa to grow invasively into the agar medium.

necessary to apply CHEF, RAPD-PCR and sugar fermentation data to achieve this objective. Furthermore, results clearly indicated that the other techniques (flocculation ability, stress resistance/response, extracellular enzyme activity and ability to form pseudohyphae/grow invasively) applied here did not in any way contribute to the unambiguous characterisation of S. cerevisiae.

Less than $50 \%$ of the yeasts isolated in the inland and coastal areas could grow invasively, while the percentage of strains able to form pseudohypahe varied between $69 \%$ and $80 \%$. These factors could therefore contribute to the organism's overwintering ability, but clearly other mechanisms must also be involved.

\section{CONCLUSIONS}

The molecular characterisation of these S. cerevisiae strains was done by electrophoretic karyotyping, with the strains isolated from the warmer, inland regions, W1-W30, further compared by means of RAPD-PCR. Evaluating these two identification techniques on the basis solely of accuracy, clarity and reliability, enables one to draw the conclusion that the electrophoretic karyotyping technique seems to be the most useful and reliable for routine profiling. The RAPD-PCR technique must, however, be used to determine if yeasts which exhibit identical CHEF banding patterns are in fact the same. Even this may not be enough, as was the case for strains W1 and W51. The combined use of the molecular, biochemical and physiological techniques then revealed that no single dominant strain was found in the 19 warmer, inland and 13 cooler, coastal wine areas studied. This 
implies that different $S$. cerevisiae strains are present at different areas in the different climate zones. Future research in this field could then possibly reveal or elucidate the extent to which the genetic diversity or the population dynamics, in these two different climatic zones, may further differ.

The fermentation potential of the indigenous yeast strains was also determined and, based on these results, many of these strains were incorporated into a hybrid breeding programme, run at the ARC-Nietbvoorbij, aimed at producing cultivar-specific wine yeast. The winemaking potential of these hybrids will then be determined, with the naturally occurring yeast possibly contributing to a unique quality being observed in the various cultivars evaluated.

\section{LITERATURE CITED}

AMERINE, M.A. \& WINKLER, A.J., 1944. Composition and quality of musts and wines of Californian grapes. Hilgardia 15, 493-673.

BARNETT, J.A., PAYNE, R.W. \& YARROW, D., 1983. Yeasts: Characteristics and identification. Cambridge University Press, Cambridge.

BENDA, I., 1964. Die Hefeflora des frankischen Weinbaugebietes. Weinberg und Keller 11, 67-80.

BIDARD, F., BONY, M., BLONDIN, B., DEQUIN, S. \& BARRE, P., 1995. The Saccharomyces cerevisiae FLO1 flocculation gene encodes for a cell surface protein. Yeast 11, 809-822.

BISSON, L.F. \& KUNKEE, R.E., 1991. Microbial interactions during wine production. In: ZEIKUS, J.F. \& JOHNSON, E.A. (eds). Mixed cultures in biothechnology. McGraw-Hill, New York, pp. 37-68.

BUSSEY, H., SACKS, W., GALLEY, D. \& SAVILLE, D., 1982. Yeast killer plasmid mutation affecting toxin secretion and activity and towin immunity function. Mol. Cell. Biol. 2, 1362-1370.

CARDINALL, G. \& MARTINI, A., 1994. Electrophoretic karyotype of authentic strains of the sensu stricto group of the genus Saccharomyces. Int. J. Syst. Bacteriol. 44, 791-797.

CARLE, G.F. \& OLSEN, M.V., 1985. An electrophoretic karyotype for yeast. Proc. Natl. Acad. Sci. USA. 82, 3756-3760.

CARSTENS, E., LAMBRECHTS, M.G. \& PRETORIUS, I.S., 1998. Flocculation, pseudohyphal development and invasive growth in commercial wine yeast strains. $S$. Afr. J. Enol. Vitic. 19, 52-61.

CAVAliERI, D., BARBERIO, E., CASAlONE, E., PINZAUTI, F., SABASTIANI, F., MORTIMER, R. \& POLSINELLI, M., 1998. Genetic and molecular diversity in Saccharomyces cerevisiae natural populations. Food Technol. Biotechnol. 36 (1), 45-50.

CHERRY, J.M., BALL, C., WENG, S., JUVIK, G., SCHMIDT, R., ADLER, C., DUNN, B., DWIGHT, S., RILES, L., MORTIMER, R.K. \& BOTSTEIN, D., 1997. Genetic and physical maps of Saccharomyces cerevisiae. Nature 387, 67-73.

DE BARROS LOPES, M., LADEN, A., HENSCHKE, P.A. \& LONGRIDGE, P., 1996. PCR differentiation of commercial yeast strains using intron splice site primers. Appl. Environ. Microbiol. 62 4514-4520.

DE BARROS LOPES, M., SODEN, A. \& GODDEN, P.W., 1998. Changes in yeast classification of relevance to winemakers. The Australian Grapegrower and Winemaker, $35-40$.

FLEET, G.H., LAFON-LAFOURCADE, S. \& RIBÉREAU-GAYON, P., 1984. Evolution of yeasts and lactic acid bacteria during fermentation and storage of bordeaux wines. Appl. Environ. Mircobiol. 48, 1034-1038.

FREZIER, V. \& DUBOURDIEAU, D., 1992. Ecology of yeast strain Saccharomyces cerevisiae during spontaneous fermentation in a Bordeaux winery. Am. J. Enol.Vitic. 43, 375-380.

GIMENO, C.J., LJUNGDAHL, P., STYLES, C.A. \& FINK, G.R., 1992. Unipolar cell division in the yeast Saccharomyces cerevisiae leads to filamentous growth: Regulation by starvation and RAS. Cell 68, 1077-1090.

FUGELSANG, K.C., 1996. Wine microbiology. Chapman \& Hill, New York, USA.

HABA, M., MULET, A. \& BERNA, A., 1997. Stability in wine differentiation of two close viticultural zones. Am. J. Enol. Vitic. 48, 285-290.

HEARD, G., 1999. Novel yeasts in winemaking - looking to the future. Food Australia 51, 347-352.

HOUTMAN, A.C. \& DU PLESSIS, C.S., 1986. The effect of grape cultivar and yeast strain on fermentation rate and concentration of volatile components in wine. S. Afr. J. Enol. Vitic. 7, 14-20.

KREGER-van RIJ, N.J.W., 1984. The yeasts, a taxonomic study. (3rd ed.). Elsevier Science Publishers BV, Amsterdam, The Netherlands.

KURTZMAN, C.P. \& FELL, J.W., 1998. The yeasts, a taxonomic study. (4th ed.). Elsevier Science Publishers BV, Amsterdam.

LAMBRECHTS, M.G., BAUER, F.F., MARMUR, J. \& PRETORIUS, I.S., 1996. Mucl, a mucin-like protein that is regulated by MSS10, is ciritical for pseudohyphal differentiation in yeast. Proc. Natl. Acad. Sci., USA. 93, 8419-8424.

LE ROUX, E.G., 1974. 'n Klimaatsindeling van die Suidwes-Kaaplandse Wynbougebiede. M.Sc. Tesis, Universiteit van Stellenbosch.

MACPHERSON, J.M., ECKSTEIN, P.E., SCOLES, G.J. \& GAJADHAR, A.A., 1993. Variability of the randomly amplified polymorphic DNA assay among thermal cyclers, and effects of primer and DNA concentration. Mol. Cell. Probes 7, 293-299.

MARTINI, A. \& VAUGHAN-MARTINI, A., 1990. Grape must fermentation: past and present. In: SPENCER, J.F.T. \& SPENCER, D.M. (eds). Yeast technology. Springer-Verlag, Berlin.

MARTINI, A., CIANI, M. \& SCORZETTI, G., 1996. Direct enumeration and isolation of wine yeasts from grape surfaces. Am. J. Enol. Vitic. 47, 435-440.

MARTINI, A., FREDERICHI, F. \& ROSINI, G., 1980. A new approach to the study of yeast ecology of natural substrates. Can. J. Microbiol. 26, 856-859.

MORTIMER, R.K., SCHILD, D., CONTOPOULOU, C.R. \& KANS, J.A., 1989. Genetic map of Saccharomyces cerevisiae. Yeast 10, 321-403.

NAUMOV, G.I., NAUMOVA, E.S., LANTTO, R.A., LOUIS, E.J. \& KORHOLA, M., 1992 Genetic homology between Saccharomyces cerevisiae and its siblings species $S$. paradoxus and S. bayanus: electrophorectic karyotypes. Yeast 8, 599-612.

NAUMOV, G.I., NAUMOVA, E.S. \& GAILLARDIN, C., 1993. Genetic and karyotypic identification of wine Saccharomyces bayanus yeasts established in France and Italy. System. Appl. Microbiol. 16, 274-279.

PARRISH, M.E. \& CORROLL, D.E., 1985. Indigenous yeasts associated with muscadine. Am. J. Enol. Vitic. 36, 165-169.

PEYNAUD, E. \& DARMERQ, S., 1959. A review on microbiological problems in wine making in France. Am. J. Enol. Vitic. 10, 69-77.

PRETORIUS, I.S., 2000. Tailoring wine yeast for the new millennium: novel approaches to the ancient art of winemaking. Yeast (in press).

PRETORIUS, I.S. \& VAN DER WESTHUIZEN, T.J., 1991. The impact of yeast genetics and recombinant DNA technology on the wine industry - A review. S. Afr. J. Enol. Vitic. 12, 3-31.

PRETORIUS, I.S., VAN DER WESTHUIZEN, T.J. \& AUGUSTYN, O.P.H., 1999. Yeast biodiversity in vineyards and wineries and its importance to the South African wine industry A review. S. Afr. J. Enol. Vitic. 20, 61-74.

RANKINE, B.C., 1968. The importance of yeasts in determining the composition and quality of wines. Vitis 7, 22-49.

ROSINI, G., FEDERICI, F. \& MARTINI, A., 1982. Yeast flora of grape berries during ripening. Microbiol. Ecology 8, 83-89.

ROSINI, G., 1984. Assessment of dominance of added yeast in wine fermentation and origin of Saccharomyces cerevisiae in winemaing. J. Gen. Appl. Microbiol. 30, 249-256.

SCHÜTZ, M. \& GAFNER, J., 1994. Dynamics of the yeast strain population during spontaneous alcoholic fermentation determined by CHEF gel elctrophoresis. Lett. Appl. Microbiol. 19, 253-257.

TÖRÖK, T., MORTIMER, R.K., ROMANO, P., SUZZI, G. \& POLSINELLI, M., 1996. Quest for wine yeasts - an old story revisited. J. Industrial Microbiol. 17, 303-313.

VAN DER WESTHUIZEN, T.J. \& PRETORIUS, I.S., 1992. The value of electrophoretic fingerprinting and karyotyping in wine yeast breeding programmes. Antonie van Leeuwenhoek 61, 249-257.

VAN DER WESTHUIZEN, T.J., AUGUSTYN, O.P.H. \& PRETORIUS, I.S., 1999. The value 
of long-chain fatty acid analysis, randomly amplified polymorphic DNA and electrophoretic karyotyping for the characterisation of wine yeast strains. S. Afr. J. Enol. Vitic. 20, 3-10.

VAN DER WESTHUIZEN, T.J., AUGUSTYN O.P.H. \& PRETORIUS, I.S., 2000a Geographical distribution of indigenous Saccharomyces cerevisiae strains isolated from South African vineyards in the cooler, coastal regions of the Western Cape in South Africa. S. Afr. J. Enol. Vitic. 21, 3-9.

VAN DER WESTHUIZEN, T.J., AUGUSTYN, O.P.H., KHAN, W. \& PRETORIUS, I.S 2000b. Seasonal variation of indigenous Saccharomyces cerevisiae strains isolated from vineyards of the Western Cape in South Africa. S. Afr. J. Enol. Vitic. 21,10-16.

VAN ROOYEN, P.C. \& TROMP, A., 1982. The effect of fermentation temperature (as induced by fermentation and must conditions) on the chemical profile and quality of a Chenin blanc wine. S. Afr. J. Enol. Vitic. 3, 75-80.

VAN ZYL, J.A. \& DU PLESSIS, L. DE W., 1961. The microbiology of South African winemaking. Part. 1. The yeasts occurring in vineyards, musts and wines. SA. J. Agric. Sci. 4, 393-403.
VAUGHAN-MARTINI, A., MARTINI, A. \& CARDINALI, G., 1993. Electrophoretic karyotyping as a taxonomic tool in the genus Saccharomyces. Antonie van Leeuwenhoek 63, 145-156

VAUGHAN-MARTINI, A. \& MARTINI, A., 1995. Facts, myths and legends on the prime industrial microorganism. J. Indust. Microbiol. 14, 514-522.

VERSAVAUD, A., COURCOUX, P., ROULlAND, C., DULUA, L. \& HALlET, J-N., 1995 Genetic diversity and geographic distribution of wild Saccharomyces cerevisiae strains from the wine-producing area of Charentes, France. Appl. Environ. Microbiol. 61, 3521-3529.

VÉZINHET, F., HALLET, J-N., VALADE, M. \& POULARD, A., 1992. Ecologocal survey of wine yeast strains by molecular methods of identification. Am. J. Enol. Vitic. 43, 83-86.

ZOECKLEIN, B.W., FUGELSANG, K.C., GUMP, B.H. \& NURY, F.S., 1995. Wine analysis and production. Chapman \& Hill, New York, USA. 